\title{
Quantifying Non-Tariff Barriers in Ukraine: A Comprehensive Trade Cost Approach
}

\author{
Christopher A. Hartwell a,b \\ ${ }^{a}$ Associate Professor \\ Kozminski University \\ Ul. Jagiellonska 57-59, Warszawa 03-301, POLAND \\ chartwell@kozminski.edu.pl \\ ${ }^{\mathrm{b}}$ President \\ CASE - Center for Social and Economic Research \\ Al. Jana Pawła II 61/212, Warszawa 00-130 POLAND \\ Christopher.hartwell@case-research.eu \\ M: $\quad+48538175826$
}

\begin{abstract}
Great strides have been made recently in the theoretical approach to quantifying non-tariff barriers. Modifying an approach proposed by Novy (2013), this note attempts to understand the extent of non-tariff barriers between Ukraine and its major trading partners in goods. By fashioning a new approach to trade in services as well, I provide the first comprehensive estimates of ad valorem equivalents of the non-tariff measures that exist in Ukraine.
\end{abstract}

Keywords: non-tariff barriers, ad valorem equivalent, trade cost approach, Ukraine JEL Codes: F10, F13, F14

\section{ACKNOWLEDGMENTS}

The author acknowledges partial funding for this effort came from the European Commission's Directorate General for Trade. Thanks to Achim Voigt and Koen Berden for their intellectual support and the editor and anonymous referee for their comments. 


\section{Quantifying Non-Tariff Barriers in Ukraine: A Comprehensive Trade Cost Approach}

\section{Introduction}

With the prospect of a Deep and Comprehensive Free Trade Agreement (DCFTA) between Ukraine and the EU becoming more likely, a major question for policymakers is the effect this agreement would have on the Ukrainian economy. Before such a question can be answered, however, there needs to be an understanding of the barriers that currently exist in Ukraine that can stifle trade, in particular the extensive web of non-tariff barriers. Unfortunately, there is very little quantification done to date on the ad valorem equivalents (AVE) of non-tariff barriers (NTBs) in reference to Ukraine apart from Movchan and Shportyuk (2008). The purpose of this note is to rectify this omission, utilizing new theoretical advances in the quantification of non-tariff barriers to examine the NTBs between Ukraine and its major trading partners: Russia, Turkey, the EU, the Eurasian Customs Union (ECU), the European Free Trade Area (EFTA), and the rest of the world.

\section{Methodology and Data}

Great strides have been made recently in the theoretical approach to quantifying non-tariff barriers. A strategy for estimating NTBs in goods was proposed by Novy (2013), who utilize a geometric average of trade costs to determine barriers unrelated to tariffs; in their estimation, NTBs also would include "all additional costs other than tariff costs involved in trading goods bilaterally rather than domestically" (Hayakawa and Kimura 2014: 6). The Hayakawa and Kimura (2014) approach utilizes trade costs structured as:

$$
\text { (1) } \tau_{i j}=\sqrt{\frac{t_{i j} t_{j i}}{t_{i i} t_{j j}}}-1=\left(\frac{x_{i i} x_{j j}}{x_{i j} x_{j i}}\right)^{\frac{1}{2(\sigma-1)}}-1
$$

Where $\mathrm{T}$ is the comprehensive trade costs between countries $I$ and $j, t$ are the trade costs between the countries, and $\mathrm{x}$ are the consumption of products (or value of products traded) from country to country or within the country (and $\sigma$ is the elasticity of substitution).

In this previous work (including Mirodout et. al 2012), the average of tariff rates was utilized to create a picture of comprehensive trading costs that existed between two bilateral partners. As we are interested primarily in asymmetric effects, we instead calculate $T R_{i j}$ as:

$$
\text { (2) } T R_{i j}=1+\text { Tariff }_{i j}
$$

NTBs can then be calculated at a tariff-equivalent basis as:

$$
\text { (3) } N T B_{i j}=100 *\left(\frac{1+\left(\tau_{i j} / 100\right)}{T R_{i j}}-1\right)
$$

For this analysis, the tariff calculations for goods, shown in equation (2), are done using the World Bank's World Integrated Trade Solutions (WITS) database by specific Global Trade Analysis Project (GTAP) sector. For broader aggregates, tariff rates were calculated as the simple average of the simple average; for example, the tariff rate for 
wheat, paddy rice, and vegetables were averaged to give a tariff rate for agriculture. Similarly, in multi-country groupings (such as the European Union), these aggregated averages were further averaged across countries.

For this exercise, as in Hayakawa and Kimura (2014), the trade costs were directly obtained from the ESCAP-World Bank Trade Cost Database for 2012 (the most recent year available). As the comprehensive trade cost is computed already, utilizing an elasticity of substitution ( $\sigma$ in equation 1 above) of 8 for all sectors, it would require extensive production data far beyond the scope of this note to create a scenario model of different elasticities. However, the chosen elasticity follows from a long line of econometric modelling of trade data: Anderson and van Wincoop (2004) survey estimates of the elasticity and conclude that it normally is between 5 to 10, while Eaton and Kortum (2002) find the baseline estimate of the elasticity as 8.3. Novy (2013) utilized 8 as his baseline, and concludes that aggregate trade flows are "not sensitive to this particular value."

This methodology is then utilized to examine the NTBs to and from Ukraine in a variety of sectors (the mapping of sectors from the World Bank GTAP database to our aggregations is based on work done previously for the European Commission (Ecorys-CASE (2007)). But while this methodology is suitable for trade in goods, unfortunately it is unable to encompass trade in services. Quantifications of NTBs in trade in services has followed a more standardized methodology, spearheaded by the World Bank (notably Jaffari and Tarr 2014). This approach encompasses the construction of a trade restrictiveness index (TRI), based on survey methods, to map out the amount of restrictions in a given services sector. To convert this TRI into an ad valorem equivalent, an econometric estimate of elasticity of substitution, derived from a gravity equation specific to each sector, is utilized and inserted into the following equation (based on Anderson and Wincoop 2003):

$$
\text { (4) } A V E=100 * e^{\sigma * T R I}-1
$$

Jaffari and Tarr (2014) have derived a series of AVEs for NTBs in services for 103 countries over 11 sectors utilizing the World Bank's Services Trade Restrictiveness Index (STRI) and a series of sector weights pulled from the extensive trade literature. In this paper, we utilize their data for Ukraine and Ukraine's trade partners, with some changes. In the first instance, they have their estimates done by country, so in the case of multi-country groupings such as the EU or Eurasian Customs Union, we perform an average of their estimates across countries. Secondly and similarly, their estimates by sector need to be aggregated to map to our broader sectors (for example, combining rail and maritime transport), and this is also done using a simple averaging.

A more nefarious issue is in regards to missing countries and sectors. Jaffari and Tarr have no data for the EFTA countries (Switzerland, Iceland, and Norway) or some of the EU-28 countries, which corresponds to gaps in the World Bank's STRI database. To overcome this issue for the EU, the numbers shown as NTBs in services are the average of all the EU countries for which data is available. ${ }^{1}$ In order to fill in the gaps for the EFTA countries, however, we utilize the STRI from the OECD, which has coverage for the EFTA countries, paired with Jaffari and Tarr's (2014) sector weightings to generate AVEs for the non-tariff barriers in services in these countries. ${ }^{2}$

Finally, and perhaps most difficult, Jaffari and Tarr also do not have estimates available for the construction or social activities sectors. To overcome this sizeable obstacle, we base the elasticities on previous literature. Utilizing Francois's (1999) approach, we set the elasticity of the construction service sector at 0.4 , reflecting its greater immobility and lower sensitivity to prices in the aggregate. This generates results for nearly every country/grouping in

\footnotetext{
${ }^{1}$ The missing countries are Croatia, Cyprus, Latvia, Estonia, Luxembourg, Malta, Slovakia, and Slovenia.

${ }^{2}$ The only sector that this did not work for was communications, which had no weighting that could be obtained: the original weighting estimated by Jaffari and Tarr was based on country-specific information that is not available for the EFTA countries.
} 
our sample, except for Ukraine, which is excluded from the OECD STRI. For this, we rely on an estimate from Kee et. al (2009) of the average service trade restrictiveness of 0.421 for Ukraine; this number comports closely with the OECD STRI of Russia, which is 0.31 for the construction industry, as well as the estimates from Castajon et. al (2008), who find that barriers to foreign ownership in the construction industry average out across all countries to an elasticity of $0.4238 .^{3}$

In regards to recreation, there are simply no international comparisons available, forcing us to be even more creative. The OECD STRI has coverage for the category "motion pictures," which was the subject of a gravity study by Hanson and Xiang (2009); their work found a trade barrier elasticity of 0.268 , which we utilize here in combination with the OECD-provided STRI. As above, where there is no data available on TRIs (as with Ukraine and the ECU), we substitute Kee et. al's (2009) country-wide averages.

\section{Results}

A detailed explanation of the results for trade in goods by partner is shown in Table 1. The first column shows the total trade cost between Ukraine and its partners (as in Novy's (2013) formulation), which the second and third column show the asymmetric effect of trade barriers from Ukraine's side or that of the partner in 2012. As can be seen, the variation across goods is quite high; to take the example of trade with Turkey, dairy products face very little barriers but the cow itself showing barriers of over $100 \%$ ! The broad results from the NTBs in goods comport with Movchan and Shportyuk (2008), and, in general, the level of protection estimated for Ukraine appears to be realistic, especially in the higher levels of NTBs in the agricultural sectors (which have been under restrictive land use practices for a decade and a half). Thus, our estimates appear to be supported by prior evidence and historical experience.

Table 1 here

An interesting question is how these NTBs in goods have evolved over time. Table 2 shows the same methodology applied to data from 2010 and 2011 for the same partner groupings. As can be seen, overall NTBs between Ukraine and most of the world have decreased over this three-year span, including with the EU-27, while they have increased somewhat with the ECU (in regards to agriculture) and remained fairly steady with Russia. ${ }^{4}$ The only huge discrepancy to these trends regards agricultural imports in EFTA in 2010, a number driven by Iceland's prohibitive tariffs on "other crops not elsewhere classified" (which reached a rate of 2,012\% that year but was removed the following year).

Table 2 here

For services, Table 3 below shows the NTBs in services for all partners to and from Ukraine in 2012. While there is little previous work quantifying the NTBs of trade in services in Ukraine, our estimates shown above are in line with other estimates of the scale of NTBs globally. For example, Walsh (2006) finds an average tariff equivalent of $72 \%$ for services measures, while our work shows data more in line with Guillin (2013), who finds a lower average tariff equivalent of around $40 \%$ across 63 countries.

Table 3 here

\footnotetext{
${ }^{3}$ Similarly, the ECU number was taken from the average of Belarus and Kazakhstan in the Kee et. al (2009) paper as data for Armenia and Tajikistan was not available. Finally, restrictiveness for the rest of the world relied on the 0.4238 elasticity of Castajon et al (2008).

${ }^{4}$ The EU grouping for 2010 and 2011 does not include Croatia, as membership was not imminent.
} 


\section{Conclusions}

This note has offered a quantification of non-tariff barriers in Ukraine, based on the latest trade methodologies. Ukraine still shows much more preferential trade towards Russia and the Eurasian Customs Union, and reduction of barriers to the EU via a DCFTA may lead to welfare gains in Ukraine. Formally modelling such a scenario has been made easier by the quantification shown here.

\section{REFERENCES}

Anderson, J., and van Wincoop, E. (2003), Gravity with gravitas: A solution to the border puzzle. American Economic Review, 93(1), pp. 170-192.

(2004). Trade Costs. Journal of Economic Literature 42(3), pp. 691-751.

Castejón, C. F., François, J. F., \& Woerz, J. (2008). Trade through FDI: Investing in services. Documentos de trabajo (Universidad de Zaragoza. Facultad de Ciencias Económicas y Empresariales), (6), 1.

Eaton, J., \& Kortum, S. (2002). Technology, geography, and trade. Econometrica, 70(5), pp. 1741-1779.

Ecorys-CASE (2007). Global Analysis Report for the EU-Ukraine TSIA. Report for the European Commission Director General for Trade, http://trade.ec.europa.eu/doclib/docs/2007/june/tradoc 135010.pdf.

Francois, J. (1999). Estimates of Barriers to Trade in Services. Rotterdam: Erasmus University.

Guillin, A. (2013). Trade in Services and Regional Trade Agreements: Do Negotiations on Services Have to be Specific? The World Economy, 36(11), pp. 1406-1423.

Hanson, G. H., \& Xiang, C. (2009). International trade in motion picture services. In Reinsdorg and Slaughter (eds.), International Trade in Services and Intangibles in the Era of Globalization. Chigao: University of Chicago Press, pp. 203-222.

Hayakawa, K., \& Kimura, F. (2014). How do free trade agreements reduce tariff rates and non-tariff barriers? Working Paper No. 446. Institute of Developing Economies, Japan External Trade Organization (JETRO).

Jaffari. Y. \& Tarr, D. (2014), Estimates of Ad Valorem Equivalents of Barriers against Foreign Suppliers of Services in Eleven Services Sectors and 103 Countries. Forthcoming World Bank Discussion Paper, October.

Looi Kee, H., Nicita, A., \& Olarreaga, M. (2009). Estimating Trade Restrictiveness Indices. Economic Journal, 119(534), pp. 172-199.

Miroudot, S., Sauvage, J., \& Shepherd, B. (2012). Trade costs and productivity in services ectors. Economics Letters, 114(1), pp. 36-38. 
Movchan, V. and Shportyuk, V. (2008). Effects of non-tariff protectionism in Ukraine: sector aspects. Paper prepared for the Tenth Annual Conference of the European Trade Study Group (ETSG), September.

Novy, D. (2013). Gravity Redux: measuring international trade costs with panel data. Economic Inquiry, 51(1), pp. 101-121.

Walsh, K. (2006). Trade in services: does gravity hold? A gravity model approach to estimating barriers to services trade. The Institute for International Integration Studies Discussion Paper Series, 183. 